\title{
LGBTI Sexualities and intersectional research: Looking for inclusion beyond gender in Adult Learning and Education (ALE) Practices
}

\author{
Rosanna Barros \\ University of Algarve, Portugal (rmbarros@ualg.pt) http://orcid.org/0000-0002-3882- \\ 1539 \\ Agustín Romero López \\ University of Almería, Spain (ar1058@ual.es) https://orcid.org/0000-0003-0573-3695 \\ Alejandro Granero Andújar \\ University of Almería, Spain (aga848@ual.es) http://orcid.org/0000-0003-2697-0964
}

\begin{abstract}
We examine testimonies pertaining to the integration of a gender perspective beyond the dichotomy man-woman into practices of affective-sexual adult learning and education (ALE). We are interested in inclusive practices able to expand voices from specific vulnerable groups against discriminations and multiple oppressions among the aged when belonging to LGBTI Communities. The narrative literature review method was chosen, and international scientific search engines and databases were consulted to find literature in Portuguese, Spanish and English. A total of 25 educational interventions were selected for analysis. To discuss the data, we resorted to Barragán Medero's (1996) theoretical models and postfeminist contributions. The results show a small number of internationally documented experiences on affective-sexual education with the elderly and adults, a prevalence of the integrative model, as well as a scant presence of the LGBTI community. We concluded that there was a need to continue with the implementation of inclusive and egalitarian affective-sexual adult experiences in ALE.
\end{abstract}

Keywords: Adult learning and education, gender minorities and intersectionality, gerontology, LGBTI, sexuality education

ISSN $2000-7426$

(c) 2021 The authors

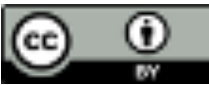

https://creativecommons.org/licenses/by/4.0/

http://doi.org/10.3384/rela.2000-7426.3316

www.rela.ep.liu.se 


\section{Introduction}

Trying to explore what is missing in a gender sensitive research agenda is an interesting challenge (Ostrouch-Kamińska \& Vieira, 2016). Representing a positive road through inclusion, feminist thinking and "gender lenses", however, have brought little attention to invisible minorities under the gender issue, as those connected with the LGBTI Communities (McAllister, 2018).

Looking for testimonies of the integration of a gender perspective beyond the dichotomy man-woman into practices of affective-sexual ALE, including the elderly, was our goal. This work is part of the initial phase of a research project on that subject. We are interested in highlighting inclusive practices able to expand voices from specific vulnerable groups against discriminations. As stated in the EU Gender Equality Strategy 2020-2025, the meaning given to gender equality is variable. However, more "sensitive research" is necessary if the purpose is to work together to build a world where women, girls, men, boys, and also intersex, trans identities and non-heterosexuality, in all their diversity, are equal - 'where they are free to pursue their chosen path in life and reach their full potential, where they have equal opportunities to thrive, and where they can equally participate' (p. 19).

Talking about affective-sexual ALE is about revealing structural inequalities, cultural norms and values which have imposed discursive binaries of "normality and abnormality" fostering an incessant interplay of unequal power relationships between human beings. Therefore, this is a specific area where we can discuss explicit and implicit forms of inequality and discrimination across the lifespan of adults and elderly persons (Mortimer \& Shanahan, 2003). In this context, conquering academic space for research is crucial, as well as highlighting effective and affective ALE able to contribute to deconstructing multiple oppressions among the ageing when belonging to LGBTI Communities (Sokan \& Teaster, 2016).

This article tries to offer an original panorama of those issues by means of the analysis of the existing literature reporting (Fejes \& Nylander, 2019; Belando-Montoro, Barros \& Lampreia-Carvalho, 2020) on internships and practices intended to carry out affective-sexual education with adults and elders. For that purpose, the narrative literature review method (Grant \& Booth, 2009) was chosen, and international scientific search engines and databases were consulted to find literature in Portuguese, Spanish and English.

\section{Theoretical framework}

\section{Adult learning and education (ALE) as a field committed with socioeducational justice}

When thinking of the role of ALE, if we consider the point of departure to be Article 26.2 of the Universal Declaration of Human Rights, that states 'education shall be directed to the full development of the human personality and to the strengthening of respect for human rights and fundamental freedoms. It shall promote understanding, tolerance, and friendship among all nations, racial or religious groups', then a vision of educational justice as something more than compulsory and free elementary education emerges. Here we agree with Tomaševski (2001) when she stated:

The importance of the right to education reaches far beyond education itself. Many individual rights are beyond the grasp of those who have been deprived of education (...) education operates as a multiplier, enhancing the enjoyment of all individual rights and 
freedoms where the right to education is effectively guaranteed, while depriving people of the enjoyment of many rights and freedoms where the right to education is denied or violated (p. 10)

As Freire (2006) has showed, it is possible to turn ALE into a condition for freedom by encouraging critical thought about unequal power structures. Also, Milana states ALE "can raise awareness of civic issues, while developing both a range of skills and knowledge and an ability to think critically" (2007, p. 8). However, this field of educational praxis presents a trajectory where "justice lenses" have been understood differently through time. Indeed, in the history of the evolution of the political meaning given to the concept of ALE, since the twentieth century the concept has remained mainly trapped in three programmatic perspectives: one relating to vocational qualification and training, another related to the campaigns of so-called functional literacy and a third inscribed in the permanent education movement (Jarvis, 1987; Titmus, 1989)

In the contemporary understanding conferred to the concept of adult learning and education, the six international conferences ${ }^{1}$ promoted by UNESCO represent important beacons, particularly by counterbalancing a restricted vision of lifelong learning (subdued to the immediate interests of the neoliberal economy) with a more enlarged vision of lifelong education, embedded with critical and humanist principles and values (Mayo \& Thompson, 1997; Barros, 2012). It is only when they are inscribed in the "great tradition" of the last paradigmatic understanding that policy and practices for an emancipatory ALE, able to contribute to the deconstruction of multiple oppressions, are possible.

Within this theorethical framework, holistic andragogical reflection has been developed by several researchers (Gitterman, 2004; Kapur, 2015; Knowles, 1980) and a range of techniques and active teaching-learning methods are made available to adult educators, seeking to ensure processes where the learning of adults and elders takes place in an appropriate and meaningful manner (Konopka, Adaime \& Mosele, 2015; Wie, 2003). A critical andragogical approach, independently of the content being studied, prioritizes, in all educational contexts (and for both types of education: formal and non formal), the need to work in collaboration and ethical integration with each other (Barth, 1996). Thus, social and communication skills are to be developed side by side with analytical and critical thinking skills to achieve higher order thinking and meta-cognition, and this, to be transformative, involves student-centred approaches as well as collaborative and inquiry-based educational processes (Mezirow, 1991).

Inclusive ALE practices for emancipation are usually inspired by critical theories and radical philosophies (Foley, 2001), and can take several different forms in which dialogue is vital. Those educational interventions and workshops attempt to help the participants to question, destabilize commonsense beliefs (in terms of their own thoughts, ideas, views, strategies, practices, etc.) and challenge the mechanisms of power and domination. The underlying ideia is to highlight the complexity of human interations to acquire an in depth understanding of alterities and what is required to respect the rights of the Other.

In effect, affective-sexual ALE is associated with those mentioned set of characteristics not always adopted in the communities of practices (Wenger, 1998), as we were able to ascertain in this study, concerned with more than the 'industrialised global North' and therefore examining different times and geographies (see table 3). However, as McAllister (2018) put it, it remains important to:

explore in more in depth and purposeful ways what may constitute empowering CEG [critical educational gerontology], particularly the pedagogic practices through which older 
LGBTI adults are enabled to counter ever shifting forms of heteronormativity as well as strengthen their participative voice to contribute to evolving social and legal reform (p. 58)

This has been the leit motif underlying the need for "sensitive research" on the existing literature reporting on internships and practices, in the field of ALE. intended to improve socioeducational justice through affective-sexual education with adults (18-60 years old) and elders (over 60 years old).

\section{Conceptual approach to affective-sexual ALE and its models}

As pointed out by Jones (2011), sexuality education is a broad concept and the ways it is conceived and understood, as well as the idiosyncratic characteristics of the experiences undertaken are the subject of multiple debates. As such, it can encompass the most varied experiences, such as workshops on reproduction, health initiatives against Sexually Transmitted Diseases (STD), talks with an underlying moral purpose based on a religioustraditional view, informal conversations, pornography and other online spaces, the media, etc. Based on this broad view of the ways of understanding how one learns about the diverse range of contents and perspectives that the field of sexuality comprises, in this paper we use the term affective-sexual education to refer to the experiences and approaches included within formal and non-formal education.

In this regard, Soler (2003) described affective-sexual education as having two parts that were differentiated by the sexual dimension and the affective dimension which, when viewed together, allowed for a better understanding of this educational field. On the one hand, sexuality education is defined as a science which is meant to provide information in a transversal manner about human sexuality with a view to it becoming a free, healthy and responsible activity. On the other hand, it was maintained that affective education fosters the addressing of self esteem needs, forms of internal control, social skills, and shared responsibility.

Over two and a half decades ago, Bredy and Barragán (1993) defined the objectives of this educational field as follows:

The aim of sexuality education is the construction of an explanatory model of human sexuality which is critical, open and in a continuous process of transformation. Going beyond the restrictive framework of exclusively biological or preventive aspects, building sexual knowledge is essential for our personal, affective and social development if one considers the various aspects it entails: getting to know ourselves and others, as well as getting to know the relationships between them within a cultural and historical context such as ours. (p. 5)

More recently the World Health Organization (WHO Regional Office for Europe, 2010), in keeping with the view of a comprehensive and values-based development, defined sexuality as:

learning about the cognitive, emotional, social, interactive and physical aspects of sexuality [...]. It equips and empowers children and young people with information, skills and positive values to understand and enjoy their sexuality, have safe and fulfilling relationships and take responsibility for their own and other people's sexual health and well-being. [...]. In this definition, the primary focus is on sexuality as a positive human potential and a source of satisfaction and pleasure. (p. 26).

According to the United Nations Educational, Scientific and Cultural Organization (UNESCO, 2011, p. 9), this field of knowledge should consider the 'state of complete 
physical, mental and social well-being and not merely the absence of disease or infirmity, in all matters relating to the reproductive system and to its functions and processes'.

This notwithstanding, different affective-sexual education models have been put forward, depending on the intended purposes and the perspective adopted (Barragán, 1996; Blair \& Monk, 2009; Britzman, 1995; Carlson, 1992; Elia, 2005; Font, 1990; Gaudreau, 1985; Haffner, 1992; Irvine, 2002; Jones, 2011; Kornblit \& Sustas, 2014; Lameiras Fernández \& Carrera Fernández, 2009; Lennerhed, 2009; López, 2005; 2019; López \& Oroz, 1999; McLaren, 1992; Swain, Warne, \& Hillel, 2004; Wainerman, Di Virgilio \& Chami, 2008). This paper will be based on the models proposed by Barragán (1996), albeit enriched with the contributions of other of the aforementioned experts. As such, we will resort to three main models: the moral, the preventive and the integrative.

The moral model, also known as repressive or traditional, is based on a moralistic Judeo-Christian approach, in which sexuality without reproductive purposes is regarded as sinful and pathological. In this sense, the sexuality model is confined to a marital context, which is heterosexual, monogamous and reproductive in nature. Its goal is to pass on to young people normative values, such as heterosexuality as the sole and correct form of affective-sexual desire, to prohibit masturbation, to condemn the use of contraceptive metods or to defend abstinence and marriage to fend off the dangers of Sexually Transmitted Diseases (STD) and unwanted pregnancies (Barragán, 1991).

In the same vein, infantile and adolescent sexuality is rejected due to the impossibility or inappropriateness of reproduction, with the aim being to preclude sexuality before adulthood and distancing it from anything that may be conceived as a pleasurable activity. This model is, therefore, characterized by the transmission of values that are conservative in nature and meant to preserve the dominant hegemonic social system. According to Lameiras and Carrera (2009), given that this model has a prohibitive view that uses fear and disgust as control tools, this type of sexuality education does not seek to educate on sexuality but to silence and repress it.

The preventive model, also known as the health model or the medicalization of sexuality education, if one is to use Foucault's (1980) terms, is based on a pathological and healthcare view of sexuality education. It is geared towards the prevention of risks that exist in sexual relations, with healthy sexuality being understood as that which is disease-free or, in what basically amounts to the same thing, associated with the physical dimension (not pychological nor social).

Although this view may be of significance since it provides one with a range of knowledge that constitutes a basis for preventing pathological risks and unwanted pregnancies, its approach to sexuality education is biased in that it favours the emergence of behaviours and attitudes that replicate and reinforce values opposing equality due to its biologistic nature, which means that corporalities, gender identities and nonhegemonic affective-sexual orientations are left out of the curriculum.

Finally, the integrative or biographical and professional model (López, 2005) starts from a integral and broad view of sexuality, which is a vital aspect that comprises various dimensions. Sexuality education is, therefore, no longer limited to issues of reproduction or health but allows for other purposes and dimensions (pleasure, communication, socialisation, knowledge, etc.); for different forms of being and desiring (the LGBTI community); for health dimensions (physical, psychological and social); for the spectrum of individuality (self-knowledge; self-pleasure and self-care); and for social vision (critical values education). 


\section{Affective-sexual ALE: inclusion beyond gender}

The LGBTI community consists of three main sectors: intersexualities; trans identities and non-heterosexualities.

We use the term intersexualities to refer to individuals who, due to their physiological characteristics, are not considered to fit within the binary sex categories: male or female. Therefore, intersex individuals break with the linearity of the requirements of a categorization model based on biological criteria (García Dauder \& Gregori, 2018). This linearity is established, in the case of males, by individuals who have testicles and a penis as main genitalia, XY chromosomes and a hormonal prevalence of androgen. In the case of females, the main genitalia are the ovaries and the uterus, XX chromosomes and a hormonal prevalence of estrogen.

Trans identities, in contrast to cis identities, refer to individuals whose gender identity does not match that which was assigned to them at birth based on physical criteria. In the wake of the hegemonic break between sex and gender, the prevailing sociocultural values give rise to the concept of ciscentrism, which can be defined as the generalized conception by which it is perceived that all people identify with the gender category determined at the time of birth for biological reasons (Granero Andújar, 2020).

Finally, the term non-heterosexualities alludes to affective-sexual identities whose affective-sexual desires are expressed among individuals of the same gender. The use of this term, instead of homosexuality, is not accidental but intentional since its meant to broaden the sole and generalized conception of homosexuality as the expression of the affective-sexual desire between individuals of the same gender and, consequently, avoid the exclusion of affective-sexual identities that can develop intragender relationships, as is the case of bisexuality (affective and/or sexual attraction to individuals of both binary genders) or pansexuality (attraction to individuals regardless of their gender and beyond binary models). Following the same grammatical intentionality as the concept of ciscentrism, heterocentrism makes reference to the socioculturally established mechanisms that exclude, overlook, or render invisible non-heterosexual individuals, assuming that all relationships consist of a man and a woman and that all people have desires and affective-sexual feelings towards the opposite gender.

In this context, the LGBTI community and equality between women and men are issues that a comprehensive, egalitarian and democratic affective-sexual education needs to address. These are issues that turn out to be complementary as a result of the symbiotic relationship established by the sociocultural mechanisms of exclusion and discrimination endured by women and by the LGBTI community. Similarly, the different dimensions or cogs in the normative system of sexuality (sex, gender, gender roles and affective-sexual orientation) operate in a concerted manner on our bodies and subjectivities to legitimize, uphold and reinforce the traditional hegemonic values pertaining to sexuality (Granero Andújar, 2020). For this reason, since the postfeminist movements, gender equality has been understood to go beyond equality between women and men and has included sectors of the population that have suffered different types of gender-based violence, as is the case of non-heterosexual, trans and intersex individuals (Butler, 2006).

Furthermore, the educational field constitutes a space within which greater attention can be given to the minorities that have been traditionally excluded and discriminated, as is the case of the LGBTI community and the gender inequalities, for three main reasons (Britzman, 1995; Epstein \& Johnson, 2000): 1) the thematic proximity of the content; 2) the fact that it is the educational space where discriminatory behaviours and values are most often exposed; 3 ) the involuntary nature of transmitted values, whether inclusive or discriminatory. 


\section{Methodology}

To achieve our goal, we used the narrative literature review method (Grant \& Booth, 2009), and a qualitative research perspective (Merriam, 2009; Stake, 2010).

The search was carried out between May and July 2020, consulting the following databases and scientific search engines: Google Académico, Dialnet, Web of Science, Research Gate, Teseo, Education Source EBSCO, CSIC, REDIB, OAIster, Redalyc, RCAAP, PudMed y Scopus.

The descriptors consulted in these databases were those relating to our object of study, i.e. affective-sexual adult learning and education (see Table 1).

Table 1. Descriptors used in the literature review

\begin{tabular}{c|c|c}
\hline $\begin{array}{c}\text { Education sector } \\
\text { descriptors }\end{array}$ & Education field descriptors & $\begin{array}{c}\text { Education } \\
\text { intervention } \\
\text { descriptors }\end{array}$ \\
\hline Personas mayores & Educación sexual & Education intervention \\
\hline Personas adultas & Educación afectivo-sexual & Workshop \\
\hline Idosos & Educação sexual & \\
\hline Pessoas adultas / adultos & Educação afetivo-sexual & \\
\hline Adult & Sexual affective education & \\
\hline Aged & Sexual affective educational & \\
\hline Old & Sexual intercourse & \\
\hline Older & Sexual education & \\
\hline Senior & Sexual learning & \\
\hline Ancient & Environments & \\
\hline Elderly population & Sex talk & \\
\hline & Sexuality education & \\
\hline & Education for sexuality & \\
\hline & Sexual health education & \\
\hline
\end{tabular}

The terms of the three columns in the table have been combined to try to achieve the maximum possible range of publications. Boolean operators were also used in the search for the same purpose. ("and", "e", "y", "o" and "or").

Freely available academic research papers written in English, Spanish and Portuguese were consulted. The criteria for selecting the analysed works were the following: 1) the articles had to report on practical experiences involving affective-sexual education with adults and elderly persons in an educational context; 2) they had to be written in English, Spanish or Portuguese. There was no specific timeframe for the search as the aim was to find as many experiences as possible that met the criteria.

Building on the interpretive approach of our research, we used coding as an analysis technique, which enabled us to conduct a thematic or sequential content analysis in various phases (see Table 2). To that end, we identified common key concepts that generated our research categories and later created clusters which would enable us to 
examine the group meanings, the discrepancies and the interrelationships present in the data that could provide us with insights into, as well knowledge and a holistic understanding of, our object of study. (Simons, 2011). Some of the categories used were a priori categories (Cisterna Cabrera, 2005), that is to say, they were determined prior to the data collection and based on readings on the topic that sought to ascertain whether the issues and processes addressed therein were present in the experiences analysed. Others emerged from questions asked during the data collection or from the data analysis itself. These were called emergent categories (Cisterna Cabrera, 2005).

It should be stessed that investigator triangulation was used for evidence of coherence betweent the results and the information provided by the participants (Sandín, 2010).

Table 2. Categories used for analysis

\begin{tabular}{|c|c|c|}
\hline $\begin{array}{l}\text { Thematic axes } \\
\text { (TA) }\end{array}$ & Categories (C) & Subcategories (S) \\
\hline \multirow{4}{*}{$\begin{array}{l}\text { TA1-Sexual } \\
\text { education model. }\end{array}$} & C1.1-Integrative model. & $\begin{array}{l}\text { S1.1.1-Variety of purposes and dimensions, } \\
\text { S1.1.2-Diversity of forms of being and desiring, } \\
\text { S1.1.3-Diferents health dimensions, S1.1.4- } \\
\text { spectrum of individuality, S1.1.5-Social vision. }\end{array}$ \\
\hline & C1.2-Preventive model. & $\begin{array}{l}\text { S1.2.1-Pathological risks, S1.2.2-Unwanted } \\
\text { pregnancies, S1.2.3-Biologistic nature } \\
\text { perspective. }\end{array}$ \\
\hline & C1.3-Moral model. & S1.3.1-Marital relationships, S1.3.2- \\
\hline & & $\begin{array}{l}\text { Heteronormativity, S1.3.3-Biologicism, S1.3.4- } \\
\text { Monogamy, S1.3.5- Sexuality limited to } \\
\text { reproduction. }\end{array}$ \\
\hline \multirow{2}{*}{$\begin{array}{l}\text { TA2-Equality men } \\
\text { and women. }\end{array}$} & C2.1-Traditional gender roles. & $\begin{array}{ll}-- & \end{array}$ \\
\hline & $\begin{array}{l}\text { C2.2-New masculinities and } \\
\text { femininities. }\end{array}$ & --- \\
\hline \multirow{3}{*}{$\begin{array}{l}\text { TA3-Presence and } \\
\text { treatment of LGBTI } \\
\text { collective. }\end{array}$} & C3.1-Non-heterosexualities & $\begin{array}{ll}-- \\
\end{array}$ \\
\hline & C3.2-Trans identities & S3.2.1-Ciscentrism, S3.2.2-Binarism. \\
\hline & C3.3-Intersexualities & --- \\
\hline
\end{tabular}

\section{Results / Findings}

Based on the defined criteria, 25 scientific and academic documents that reported on experiences pertaining to our object of study in different countries were selected (Table 3). In an initial selection, 91 studies were identified, of which 66 were discarded after a closer review and more thorough analysis of their content. 
Table 3. Results obtained from the different experiences (in chronological order)

\begin{tabular}{|c|c|c|c|c|c|}
\hline Reference & Country & $\begin{array}{l}\text { Number (N) and } \\
\text { age of participants }\end{array}$ & $\begin{array}{c}\text { Type of } \\
\text { education }\end{array}$ & Target group & Brief Description \\
\hline $\begin{array}{l}\text { O'Neil \& } \\
\text { Carroll } \\
(1988)\end{array}$ & USA & $\begin{array}{c}\mathrm{N}=84 \\
\text { Age: } 30-38 \text { years }\end{array}$ & Non formal & Healthcare staff & $\begin{array}{l}\text { Workshop on gender roles and sexism to assist health professionals in their socialization and gender conflicts with the purpose of overcoming all possible gender- } \\
\text { motivated barricrs. }\end{array}$ \\
\hline $\begin{array}{l}\text { Goldman \& } \\
\text { Carroll } \\
(1990)\end{array}$ & USA & $\begin{array}{c}\mathrm{N}=20 \\
\text { Age: } 55-75 \text { years }\end{array}$ & Non formal & Couples & Intervention on physiological and psychological changes in sexual response during the ageing process and erectile dysfunction \\
\hline $\begin{array}{c}\text { Adams et al. } \\
(1990)\end{array}$ & USA & $\begin{array}{c}\mathrm{N}=10 \\
\text { Age: } 60-91 \text { years }\end{array}$ & Non formal & Elderly people & $\begin{array}{l}\text { Educational intervention on the different aspects (myths and stereotypes about sexuality and aging, sexual attitudes, and expressions in later life and physiological } \\
\text { and physical aspects of sexuality) connected with sexuality in elderly people }\end{array}$ \\
\hline $\begin{array}{c}\text { Pastor et al. } \\
\text { (1992) }\end{array}$ & Spain & $\begin{array}{c}\mathrm{N}=97 \\
\text { Average: } 34.5 \text { years }\end{array}$ & Non formal & Adult Students & $\begin{array}{l}\text { An eight-hour affective-sexual education course that addressed different dimensions of sexuality was drawn up and implemented (psychosexual development and } \\
\text { gender roles). }\end{array}$ \\
\hline $\begin{array}{c}\text { Risman } \\
(1993)\end{array}$ & Brazil & $\begin{array}{c}\mathrm{N}=128 \\
\text { Age: }<60 \text { years }\end{array}$ & Formal & third age Students & $\begin{array}{l}\text { Sexuality education program with the third age student body of the Gama Filho University (UGF), which addressed social prejudices pertaining to gender, the } \\
\text { understanding of one's own body and affective-sexual orientations. }\end{array}$ \\
\hline Livni (1994) & outh Africa & $\begin{array}{c}\mathrm{N}=183 \\
\text { Age: Not specified }\end{array}$ & Non formal & Healthcare staff & $\begin{array}{l}\text { Experience developed to improve sexual health (healthy sexual behavior and sexual relationships) between elderly couples of whom one member had some kind } \\
\text { of dementia. }\end{array}$ \\
\hline $\begin{array}{c}\text { Mayers \& } \\
\text { McBride } \\
(1998)\end{array}$ & USA & $\begin{array}{c}\mathrm{N}=27 \\
\text { Age: } \text { Not specified }\end{array}$ & Non formal & Healthcare staff & $\begin{array}{l}\text { Programme aimed at changing the attitudes and prejudices of healthcare staff about the sexuality of the elderly, focusing oh: attitude toward sexuality, } \\
\text { terminology and communication and rights their sexuality rights. }\end{array}$ \\
\hline $\begin{array}{c}\text { Klein et al. } \\
\text { (2005) }\end{array}$ & USA & $\begin{array}{c}\mathrm{N}=174 \\
\text { Age: } 19-77 \text { years }\end{array}$ & Non formal & Parents & $\begin{array}{l}\text { Intervention programme seeking to improve communication on sexuality between parents and children and to provide tools to further knowledge of sexuality, } \\
\text { which focused on communication barriers, how to express emotions and feelings, anatomy and understanding the human body. }\end{array}$ \\
\hline $\begin{array}{l}\text { Nicols et al. } \\
\text { (2007) }\end{array}$ & USA & $\begin{array}{c}\mathrm{N}=37 \\
\text { Age: } \text { Not specified }\end{array}$ & Non formal & Mothers & $\begin{array}{l}\text { Programme focused on providing mothers with the necessary tools and knowledge to become engaged in the sexuality education of their children. It focused on } \\
\text { children's sex education needs at all developmental stages, selected sexuality information, and communication skills. }\end{array}$ \\
\hline $\begin{array}{c}\text { Rodriguez } \\
(2009)\end{array}$ & Cuba & $\begin{array}{c}\mathrm{N}=32 \\
\text { Average: } 22 \text { years }\end{array}$ & Formal & Young Adults & $\begin{array}{l}\text { Affective-sexual education project carried out within the "Calixto Garcia Iñiguez" Comprehensive Improvement Course for Young People. Issues covered } \\
\text { included sexual reproduction, the risks and consequences of abortion, pregnancy and STDs. }\end{array}$ \\
\hline $\begin{array}{l}\text { Di Gioia } \\
(2011)\end{array}$ & USA & $\begin{array}{l}\text { Age: Not specified } \\
\text { Age: }<40 \text { years }\end{array}$ & Non formal & Older adults & $\begin{array}{l}\text { Experience intended to get the participants to reflect on the relationship between their sexuality and their religious beliefs. Among the issues covered, we } \\
\text { highlight the following: attitudes and beliefs about sexual decisions, relationships, and feelings about one's sexuality }\end{array}$ \\
\hline $\begin{array}{l}\text { Cardoso } \\
(2012)\end{array}$ & Brazil & $\begin{array}{c}\mathrm{N}=20 \\
\text { Age: } 48-90 \text { years. }\end{array}$ & Formal & Elderly people & $\begin{array}{l}\text { An experience with a group of elderly people from the Clinica Escola da Faculdade de Ciências Médicas de Campina Grande. STD prevention and healthy sexual } \\
\text { practices were topics covered. }\end{array}$ \\
\hline $\begin{array}{l}\text { Baldissera, } \\
\text { et al. (2012) }\end{array}$ & Brazil & $\begin{array}{c}\mathrm{N}=20 \\
\text { Age: }<60 \text { years }\end{array}$ & Non formal & Women & $\begin{array}{l}\text { The different ways women over the age of } 60 \text { experimented with their sexuality so as to improve it were examined through the lense of the emancipatpry } \\
\text { educational approach as proposed by Freire. It focused on gender relations, family and social roles aiming to stimulate reflections about the experiences lived by } \\
\text { the women. }\end{array}$ \\
\hline $\begin{array}{l}\text { Bauer et al. } \\
\text { (2013) }\end{array}$ & Australia & $\begin{array}{c}\mathrm{N}=112 \\
\text { Age: } 18-51 \text { years }\end{array}$ & Non formal & Healthcare staff & $\begin{array}{l}\text { Educational intervention to train nursing staff. What is proposed is an improvement in the knowledge of and in attitudes towards the sexuality of the elderly in the } \\
\text { context of old-age homes. It focused on barriers to the expression of sexuality in the elderly community and the role of the health professional }\end{array}$ \\
\hline $\begin{array}{c}\text { Colarossi et } \\
\text { al. (2014) }\end{array}$ & USA & $\begin{array}{c}\mathrm{N}=71 \\
\text { Age: } \text { Not specified }\end{array}$ & Non formal & $\begin{array}{c}\text { Parents and legal } \\
\text { guardians }\end{array}$ & $\begin{array}{l}\text { Educational experience aimed at improving communication on sexuality between parents/legal guardians and their children to improve sexual health (STDs } \\
\text { unwanted pregnancies and communication barriers,) }\end{array}$ \\
\hline $\begin{array}{l}\text { Gedin \& } \\
\text { Resnick } \\
(2014)\end{array}$ & USA & $\begin{array}{c}N=21 \\
\text { Age: }<55 \text { years }\end{array}$ & Non formal & Elderly people & Intervention with the elderly to inform them on STDs and HIV due to their high prevalence among this sector of the population. \\
\hline $\begin{array}{l}\text { Ballester- } \\
\text { Amal et al. } \\
(2014)\end{array}$ & Spain & $\begin{array}{c}\mathrm{N}=120 \\
\text { Age: }<55 \text { years }\end{array}$ & Formal & Adult Students & $\begin{array}{l}\text { Experience developed over } 17 \text { years as the Sexuality Education module of the "Education for Health" subject at the Universitat per a Majors (Universitat Jaume I } \\
\text { de Castellón). Issues covered included: false beliefs and prejudices that hindered their enjoyment of sex, sexual anatomy and non-coital centered sexuality. }\end{array}$ \\
\hline $\begin{array}{l}\text { Jones \& } \\
\text { Moyle } \\
(2016)\end{array}$ & Australia & $\begin{array}{c}\mathrm{N}=42 \\
\text { Average: } 38 \text { years }\end{array}$ & Non formal & Healthcare staff & $\begin{array}{l}\text { E-learning educational intervention to improve knowledge and attitudes of healthcare (healthy sexual behavior and sexual relationships) staff so they can be more } \\
\text { attentive to elderly people who display signs of dementia. }\end{array}$ \\
\hline
\end{tabular}

After a content analysis of the various educational interventions, it was ascertained that the majority $(n=17)$, used active teaching-learning methods and belonged to the integrative model (Adams et al., 1990; Baldissera et al., 2012; Ballester-Arnal et al., 2016; Bauer et al., 2013; DiGioia, 2011; Feuz et al., 2019; Hernández Carrasco et al., 2019; Klein et al., 2005; Lee et al., 2020; Martin et al., 2018; Mayers \& McBride, 1998; Nicols et al., 2007; O’Neil \& Carroll, 1988; Opazo Pérez, 2018; Pastor et al., 1992; Risman, 2011; Vitória, 2019). A slightly lower number $(n=8)$ was consistent with the preventive model (Cardoso Junior, 2012; Colarossi et al., 2014; Gedin \& Resnick, 2014; Goldberger, 2018; Goldman \& Carroll, 1990; Jones \& Moyle, 2016; Livni, 1994; Rodríguez Maresma, 2009) while none had the features of the moral model $(n=0)$.

The issue of equality between men and women was only addressed in three interventions (Ballester-Arnal et al., 2016; O’Neil \& Carroll, 1988; Pastor et al., 1992). The experiences reported in O'Neil \& Carroll (1988) and Pastor et al. (1992) focused on analysing the influence and sociocultural restrictions of the traditional gender roles, as well as the new forms of masculinities and femininities as opposed to the ways of being and feeling based on being either a man or a woman. In the case of Ballester-Arnal et al. (2016), equality between men and women takes on an essentially biologistic perspective by considering the importance of the clitoris in female pleasure and the marginal importance of the size of the penis in men.

Regarding issues pertaining to LGBTI identities and corporalities, the analysis reveals vast differences in the experiences. Based on a more quantitative analysis, it was found that six of the experiences (Ballester-Arnal et al., 2016; Bauer et al., 2013; Goldberger, 2018; Opazo Pérez, 2018; Pastor et al., 1992; Risman, 2011) addressed nonheterosexualities. From a qualitative perspective, it was observed that the possibilities of affective-sexual orientation were reduced to the most visible ones (heterosexuality, homosexuality, and bisexuality). As far as the trans identities are concerned, they were 
only mentioned in two of the experiences (Lee et al., 2020; Martin et al., 2018). Finally, none of the studies conducted made any reference to intersexualities.

Going beyond the analysis of the presence of the LGBTI community, what was found was that some of the experiences replicated discriminatory aspects, even when using active teaching-learning methods. In this sense, the experiences (formal and non formal) laid out in Ballester-Arnal et al. (2016), Goldberg (2018) and Risman (2011) were based on a ciscentric perspective which linked sex characteristics to gender. To be a "woman" one had to have a vulva while the gender category of "man" was linked to the penis. Furthermore, in none of these experiences were trans identities addressed.

Discriminatory aspects regarding the diversity of gender were found in the content of the affective-sexual education (non-formal) implemented in Adams et al. (1990). It was based on a binary gender perspective in that it only made reference to the categories of "man "and "woman", thereby excluding non-binary gender individuals.

Concurrently, some of the studies analysed were not clear as: i) to whether it was concerned with student-centred approaches as well as collaborative and inquiry-based educational processes (to achieve critical thinking skills); ii) to whether it was equality between women and men that was addressed or the LGBTI community (Baldissera et al., 2012; Jones \& Moyle, 2016; Lee et al., 2020; Vitòria de Almeida, 2019). For that reason, it was not possible to ascertain whether they were based on an ability to think critically and achieve an equality perspective between men and women and the LGBTI community.

\section{Conclusion}

The findings show the limited number of documented international experiences on affective-sexual education with adults and the elderly. Such scarcity underlines the need for a greater attention to be given by the scientific and academic community so that this education field involving this sector of the population can be further studied and rendered visible. Concurrently, it may be a reflection of the limited presence of sexuality in adult and elderly education.

When it comes to how gender is addressed, the results bring to light the limited number of experiences that deal with equality between women and men. One can thus state that gender equality is not a recurrent theme when addressing sexuality in ALE. Meanwhile, the number of experiences addressing non-heterosexualities exceeded those focusing on the equality between women and men. This notwithstanding, and based on a holistic analysis, the number of experiences addressing non-heterosexualities was still very limited bearing in mind the total number of experiences studied. At the same time, and regardless of the results on non-heterosexualities, trans identities were almost completely absent from these experiences. Finally, and in line with Granero Andújar and García Gómez (2020), intersexualities remain completely forgotten in educational realities as they were not addressed in any of the experiences studied. In this vein, Sherlock (2015) points out how LGTBI identities and corporalities have been silenced and rendered invisible by not being addressed in affective-sexual education as they are regarded as politically incorrect by the prevailing social views.

Drawing on different scientific contributions, one may consider that the LGTBI community is often not addressed due to fear of and resistance from the prevailing normative sociocultural views, as well as to the teaching staff's lack of knowledge (Franco-Morales, Correa-Molina, Venet \& Pérez-Bedoya, 2016). The latter arises from the absence of non-hegemonic sexualities in initial and continuous teacher training (Sánchez Torrejón, 2021; Wynee, 2008). Thus, due to social pressure and internalized 
hegemonic views, non-heterosexualities, trans identities and intersexualities have either become taboos or difficult topics to be addressed by teachers who, ultimately, opt to exclude them from the contents of their lessons and focus on socially accepted topics.

In addition to the limited presence of trans identities, some of the experiences replicated ciscentric values that deny the presence and social existence of these identities. Furthermore, this ciscentric perspective entails a biological deterministic concept based on which essentialist currents have historically associated the behaviours, desires and social roles of men and women to biological aspects. Thus, the sociocultural differences, inequalities and discriminations women have endured throughout times are underpinned by supposedly natural criteria based on a biological rationale that justifies the existence of the disparities while preventing them from being questioned from a sociocultural point of view (Camaraco Cuevas \& Orm Saab, 2011). Similarly, a binary gender perspective was to be found in some of the experiences studied. This perspective entails the interiorization of a dichotomic view of the categories of "man" and "woman" as antagonic but complementary categories, legitimizing inequalities and gender-based violence, as well as heterocentrism as being socioculturally dominant. In their work, Grotz, Díaz, González \& Plaza (2016) show how the implementation of a non-binary affective-sexual education allows for the socioeducational inclusion of more realities and identities. Furthermore, it is significant that most of the experiences that worked on nonheterosexual orientations replicated excluding and discriminatory content, which made trans identities invisible by omission.

This omission from the contents together with the replication of discriminatory aspects give rise to a feeling of exclusion among the members of this community (Hobaica \& Kwon, 2017). This in turn means that affective-sexual education practices are of no use to them as they neither address their realities nor meet their needs (Estes, 2016). Another consequence is that their educational needs are not atended to, which forces LGTBI individuals to resort to informal education means that are of questionable accuracy (the internet, pornography...) to meet the learning needs and wants that have not been atended to (Currin et al., 2017).

The social repercussions this entails should also be highlighted. The omission of nonnormative forms of sexuality, together with the existence of discriminatory values, replicates and legitimizes the "normalisation" and "naturalisation" of hegemonic sexualities, which then prevail within the status quo (Sánchez Sainz, 2009). Similarly, the replication of the perception of sexuality as confined to normativity contributes to the classification, hierarchisation and disciplining of desires, identities and bodies. Among the students, this generates and legitimises the formation of subjectivities that are naturalised through exclusions, discrimination and oppression against non-hegemonic identities and corporalities, contributing to the social censure they are subject to.

Regarding the model used and the age group, the results show that all the experiences undertaken with elderly persons used the integrative model. Also, the absence of the moral model, as well as the prevalence of the integrative model in relation to the preventive one, may be connected with the age of the target population. Promoting values and behaviours associated with those models, such as sexual abstinence to postponement of the start of sexual intercourse or the prevention of STDs and unwanted pregnancies, among adults and the elderly does not make sense due to the high level of experience and knowledge this sector of the population is expected to have when it comes to sexuality. In contrast, if one is to consider that children or the young population do not yet have affective and /or sexual relations or are beginning to have them, then educating them on the dangers and the traditional moral-related values advocating abstinence or delaying the start of sexual activity is a more widespread practice. It is also necessary to break down 
the traditional sociocultural barriers regarding sexuality that have been strongly linked to the older generations (Goldberger, 2018; Hernández Carrasco et al., 2019).

On the other hand, there are correlations between the model used and the presence of the LGBTI community, in that most of the experiences in which non-heterosexualities are addressed involve the integrative model, while that is the case only once in the preventive model. Similarly, it is in the integrative model experiences that the scant presence of trans identities are to be felt. Likewise, all the experiences in which equality between women and men was addressed featured this model.

Today, people who question social mandates have been gaining increasing visibility, therefore the ways in which education is thought and discussed must be attentive to these realities and needs that are emerging and getting social visibility. In this sense, and considering the findings, it is necessary to undertake integral affective-sexual education experiences with the adult and elderly population, paying careful attention to possible discriminations and exclusions which, both explicitly and implicitly, may be replicated in those educational experiences. We should not forget that the field of affective-sexual education is regarded as the educational area with the greatest potential to work towards an education that allows for the principle of equal rights and opportunities in the field of sexuality (Epstein \& Johnson, 2000). The perspective adopted should be transversal to all educational contents, processes, actions and discourses (Mezirow, 1991) to ensure it addresses all the dimensions and discriminations of the normative sexuality system to achieve an affective-sexual education that is deeply egalitarian and democratic.

To that end, and in line with what was set out in the previously mentioned conferences, ALE should review the purposes it serves and also how it is implemented so as to embrace a holistic approach which considers affective-sexual education with a critical focus that will allow for an empowering development of sexuality among the adult and elderly population. In these educational contexts it is therefore key that there is a questioning of the hegemonic sociocultural canons and concepts surrounding sexuality, which from a postfeminist point of view are considered as domination mechanisms (Butler, 2006), so as to dismantle the power mechanisms and contribute to the social emancipation of what is known as "sexual minorities".

\section{Notes}

${ }^{1}$ Carried out in 1949, 1960, 1972, 1982, 1997 and 2009.

\section{Acknowledgements}

This work is funded by National Funds through FCT - Foundation for Science and Technology under the Project UIDB/05739/2020.

\section{References}

Adams, M.A., Rojas-Camero, C., \& Clayton, K.K. (1990). A small-group sex education/intervention model for the well elderly: A challenge for educators. Educational Gerontology, 16(6), 601-608. https://doi.org/10.1080/0380127900160609 
Baldissera, V.D., Villela Bueno, S.M., \& Hoga, L. (2012). Improvement of Older Women's Sexuality Through Emancipatory Education. Health Care for Women International, 33(10), 956-972. https://doi.org/10.1080/07399332.2012.684986

Ballester-Arnal, R., Giménez-Ruiz, C., Castro-Calvo, J., \& Morell-Mengual, V. (2016). La educación sexual dirigida a personas mayores: retos, dificultades y propuestas. In J.L. Castejón Costa (Ed.). Psicología y Educación: Presente y futuro (pp. 538-546). ACIPE- Asociación Científica de Psicología y Educación.

Barragán Medero, F. (1991). La educación sexual: guía teórica y práctica. Paidós.

Barragán Medero, F. (1996). La educación afectiva y sexual en Andalucía: la evaluación cualitativa de programas. Instituto Andaluz de la Mujer.

Barros, R. (2012). From Lifelong Education to Lifelong Learning: Discussion of some effects of today's neoliberal policies. RELA - European Journal for Research on the Education and Learning of Adults, 3(2), 119-134. http:/www.rela.ep.liu.se/article.asp?DOI=10.3384/rela.20007426.rela0071

Bauer, M., McAuliffe, L., Nay, R., \& Chenco, C. (2013). Sexuality in older adults: Effect of an education intervention on attitudes and beliefs of residential aged care staff. Educational Gerontology, 39(2), 82-91. https://doi.org/10.1080/03601277.2012.682953

Barth, B.M. (1996). L'Adulte en Formation - Regards Pluriels. De Boeck Université.

Belando-Montoro, M., Barros, R., \& Lampreia-Carvalho, F. (2020). Adult learning and education in Spain and Portugal: an interpretative study of doctoral theses (2006-2018). IJLE - International Journal of Lifelong Education, 39 (4), 1-17. https://doi.org/10.1080/02601370.2020.1817165

Blair, A., \& Monk, D. (2009). Sex education and the law in England and Wales: The importance of legal narratives. In L.D.H. Sauerteig \& R. Davidson (Eds.). Shaping sexual knowledge: A cultural history of sex education in twentieth century Europe (pp. 37-54). Routledge.

Bredy, C., \& Barragán, F. (1993). Niñas, niños, maestros, maestras: una propuesta de educación sexual. Díada.

Britzman, D. (1995). What is thing called love?. Taboo, 1(1), 65-93.

Butler, J. (2006). Deshacer el género. Paidós.

Camaraco Cuevas, M., \& Orm Saab, K.A. (2011). Sexualidad Masculina Patriarcal: Improntas culturales que ensombrecen el rostro humano de los hombres y la vida de las mujeres. Revista Estudios Culturales, 4(8), 161-174.

Cardoso Junior, R. (2012). Educação sexual na terceira idade: prevenção de dsts e promoção da saúde do idoso (Proyecto de extensión). Centro de Ensino Superior e Desenvolvimento, Campina Grande, Brasil.

Carlson, D.L. (1992). Identity conflict and change. In J.T. Sears (Ed.). Sexuality and the curriculum: The politics and practices of sexuality education (pp. 34-58). Teachers College Press.

Cisterna Cabrera, F. (2005). Categorización y triangulación como procesos de validación del conocimiento en investigación cualitativa. Theoria, 14(1), 61-71. http://www.redalyc.org/articulo.oa?id=29900107

Colarossi, L., Silver, E.J., Dean, R., Perez, A., \& Rivera, A. (2014). Adult Role Models: Feasibility, Acceptability, and Initial Outcomes for Sex Education. American Journal of Sexuality Education, 9(2), 155-175. https://doi.org/10.1080/15546128.2014.903815

Currin, J.M., Hubach, R.D., Durham, A.R., Kavanaugh, K.E., Vineyard Z. \& Croff, J.M. (2017). How gay and bisexual men compensate for the lack of meaningful sex education in a socially conservative state. Sexuality, Society and Learning, 17(6), 667-681.

DiGioia, M.K. (2011). Sexuality. What's Spirituality Got to Do With it? American Journal of Sexuality Education, 6(1), 104-113. https://doi.org/10.1080/15546128.2011.547380

Elia, J.P. (2005). Sexuality education. In J.T. Sears (Ed.). Youth, education, sexualities: An international encyclopedia (pp. 785-789). Greenwood Press.

Epstein, D., \& Johnson, R. (2000). Sexualidades e institución escolar. Morata

Estes, M.L. (2016). "Well if there's one benefit, you're not going to get pregnant”: A qualitative investigation of the sex education that gay, lesbian, and bisexual individuals received (Doctoral Thesis). Middle Tennessee State University, Tennessee, United States. https://jewlscholar.mtsu.edu/handle/mtsu/4887

Fejes, A., \& Nylander, E. (2019). Mapping out the Research Field of Adult Education and Learning. Springer.

Feuz, C., Tse, K., Kwan, M., Hill, C., Rakaric, P., Tan, K., \& Rosewall, T. (2019). Implementing Workshops to Improve Radiation Therapists' Knowledge and Attitudes about Sexual Health Issues in Cancer Patients. Journal of Medical Imaging and Radiation Sciences, 50(1), 98-105. https://doi.org/10.1016/j.jmir.2018.08.001 
Foley, G. (2001). Radical Adult Education and Learning. International Journal of Lifelong Education, 20(1/2), 71-88

Font, P. (1990). Pedagogía de la sexualidad. Grao.

Foucault, M. (1980). Microfisica del poder. La Piqueta.

Franco-Morales, F., Correa-Molina, E., Venet, M., \& Pérez-Bedoya, S. (2016). Relación actitudesconocimientos sobre diversidad sexual en una muestra universitaria colombiana. Magis: Revista Internacional de Investigación en Educación, 8(17), 135-156. https://dialnet.unirioja.es/servlet/articulo?codigo $=5381714$

Freire, P. (2006). Pedagogy of the Oppressed (30th Anniversary edition). Bloomsbury.

García Dauder, D., \& Gregori Flor, N. (2018). Intersexualidades. In L. Platero, M. Rosón \& E. Ortega (Eds.). Barbarismos queer y otras esdrújulas (pp. 272-280). Ediciones Bellaterra.

Gaudreau, L. (1985). Les caracteristiques de l'enseignant et de l'enseignate dans les programmes d'éducation sexuelle (Doctoral Thesis). Université du Québec à Montréal, Montreal, Canadá. http://depositum.uqat.ca/374/1/giselemaheux1.pdf

Gedin, T.C., \& Resnick, B. (2014). Increasing Risk Awareness and Facilitating Safe Sexual Activity Among Older Adults in Senior Housing. Journal of Community Health Nursing, 31(4), 187-197. https://doi.org/10.1080/07370016.2014.958390

Gitterman, A. (2004). Interactive Andragogy: Principles, Methods, and Skills. Journal of Teaching in Social Work, 24(3/4), 95-112. https://www.bu.edu/ssw/files/2010/11/Alex-Gitterman1.pdf

Goldberger, R. (2018). A Critical Literature Review of Barriers to Sexual Health Care for the Older Adult Population with a Proposed Intervention. University of Pittsburgh. http://dscholarship.pitt.edu/35085/1/GoldbergerRachel_finalthesis_8_2018.pdf

Goldman, A., \& Carroll, J.L. (1990). Educational intervention as an adjunct to treatment of erectile dysfunction in older couples. Journal of Sex and Marital Therapy, 16(3), 127-141. https://doi.org/10.1080/00926239008405259

Granero Andújar, A. (2020). Presencia y tratamiento del colectivo LGTBIQ en la educación afectivasexual desarrollada en el marco del Programa Forma Joven (Unpublished Doctoral Thesis). University of Almería, Almería, España.

Granero Andújar, A., \& García Gómez, T. (2020). Las intersexualidades en la educación afectiva-sexual: análisis sobre su presencia y tratamiento. Revista Educar, 56(2), 439-456. https://doi.org/10.5565/rev/educar.1092

Grant, M., \& Booth, A. (2009). A typology of reviews: an analysis of 14 review types and associated methodologies. Health Information and Libraries Journal, 26(2), 91-108. https://pubmed.ncbi.nlm.nih.gov/19490148/

Grotz, E., Díaz, A., González, M.C., \& Plaza M.V. (2016). La educación sexual del colectivo trans: una comparación entre el currículo real de un bachillerato popular y el prescripto en los lineamientos curriculares nacionales de Argentina. Bio-grafía. Escritos sobre la Biología y su enseñanza, 9(16), 205-222. https://doi.org/10.17227/20271034.vol.9num.16bio-grafia205.222

Haffner, D.W. (1992). Sexuality education in policy and practice. In J.T. Sears (Ed.). Sexuality and the curriculum: The politics and practices of sexuality education (pp. 7-8). Teachers College Press.

Hernández Carrasco, M., de la Fuente Ballesteros, S.L., García Granja, N., Hidalgo Benito, A., García Álvarez, I., \& Cano Pazos, M. (2019). Characteristics of the sexual sphere in elderly patients. Semergen, 45(1), 37-43. https://doi.org/10.1016/j.semerg.2018.09.007

Hobaica, S., \& Kwon, P. (2017). “This Is How You Hetero:” Sexual Minorities in Heteronormative Sex Education. American Journal of Sexuality Education, 12(4), 423-450.

Irvine, J. (2002). Talk about sex: The battles over sex education in the United States. University of California Press. https://doi.org/10.1080/15546128.2017.1399491

Jarvis, P. (1987). Twentieth Century Thinkers in Adult Education. Routledge.

Jones, T. (2011). A Sexuality Education Discourses Framework: Conservative, Liberal, Critical, and Postmodern. American Journal of Sexuality Education, 6, 133-175. https://doi.org/10.1080/15546128.2011.571935

Jones, C., \& Moyle, W. (2016). Sexuality \& dementia: An eLearning resource to improve knowledge and attitudes of aged-care staff. Educational Gerontology, 42(8), 563-571. https://doi.org/10.1080/03601277.2016.1205373

Kapur, S. (2015). Andragogy: The Adult Learning Theory. Indian Journal of Adult Education, 76(2), 5060.

Klein, J.D., Sabaratnam, P., Pazos, B., Auerbach, M.M., Havens, C.G., \& Brach, M.J. (2005). Evaluation of the parents as primary sexuality educators program. Journal of Adolescent Health, 37(3), 94-99. https://doi.org/10.1016/j.jadohealth.2005.05.004 
Knowles, M. S. (1980). The Modern Practice of Adult Education - From Pedagogy to Andragogy. Adult Education.

Konopka, C., Adaime, M., \& Mosele, P. (2015). Active Teaching and Learning Methodologies: Some Considerations. Creative Education, 6, 1536-1545. http://dx.doi.org/10.4236/ce.2015.614154

Kornblit, A., \& Sustas, S. (2014). La sexualidad va a la escuela. Biblos.

Lameiras Fernández, M., \& Carrera Fernández, M.V. (2009). Educación sexual: de la teoría a la práctica. Pirámide.

Lee, P.I., Lai, H.R., Lin, P.C., Kuo, S.Y., Lin, Y.K., Chen, S.R., \& Lee, P.H. (2020). Effects of a parenting sexual education program for immigrant parents: A cluster randomized trial. Patient Education and Counseling, 103(2), 343-349. https://doi.org/10.1016/j.pec.2019.08.027

Lennerhed, L. (2009). Taking the middle way: Sex education debates in Sweden in the early twentieth century. In L.D.H. Sauerteig \& R. Davidson (Eds.). Shaping sexual knowledge: A cultural history of sex education in twentieth century Europe (pp. 19-36). Routledge.

Livni, M.D. (1994). Nurses' Attitudes Toward Sexuality and Dementia: Measurement of the Effects of an Education Program. American Journal of Geriatric Psychiatry, 2(4), 338-345. https://doi.org/10.1097/00019442-199402040-00009

López Sánchez, F. (2005). La educación sexual. Biblioteca Nueva.

López Sánchez, F. (2019). El tratamiento de la educación sexual en la actualidad. Revista CONVIVES, 26, $17-24$

López, F., \& Oroz, A. (1999). Para comprender la vida sexual del adolescente. Verbo Divino.

Martin, J., Riazi, H., Firoozi, A., \& Nasiri, M. (2018). A sex education programme for mothers in Iran: Does preschool children's sex education influence mothers' knowledge and attitudes? Sex Education, 18(2), 219-230. https://doi.org/10.1080/14681811.2018.1428547

Mayers, K.S., \& McBride, D. (1998). Sexuality training for caretakers of geriatric residents in long term care facilities. Sexuality and Disability, 16(3), 227-236. https://doi.org/10.1023/A:1023003310885

Mayo, M., \& Thompson, J. (1997). Adult Learning Critical Intelligence and Social Change. NIACE.

Mezirow, J. (1991). Transformative dimensions of adult learning. Jossey-Bass Publishers.

McAllister, C. (2018). Developing inclusive later life learning environments: insights from intersectional analysis of ageing and lesbian, gay, transgendered and bisexual identities. RELA-European Journal for Research on the Education and Learning of Adults, 9(1), 45-60. http://www.rela.ep.liu.se/article.asp?DOI=10.3384/rela.2000-7426.rela9105

McLaren, P. (1992). Border anxiety and sexuality politics. In J.T. Sears (Ed.). Sexuality and the curriculum: The politics and practices of sexuality education (pp. 9-14). Teachers College Press.

Merriam, S.B. (2009). Qualitative research: A guide to design and implementation. Jossey-Bass.

Milana, M. (2007). Adult Education for Democratic Citizenship: A review of the research literature in 9 European countries - Synthesis Report (not published).

Mortimer, J., \& Shanahan, M. (2003). Handbook of the Life Course. Springer.

Nicols, J., Edd, C., \& York, N. (2007). A Sex Education Program for Mothers: Effects, Parent Characteristics, and Practice Insights. American Journal of Sexuality Education, 3(1), 39-64. https://doi.org/10.1300/J455v03n01

O’Neil, J.M., \& Carroll, M.R. (1988). A Gender Role Workshop Focused on Sexism, Gender Role Conflict, and the Gender Role Journey. Journal of Counseling \& Development, 67(3), 193-197. https://doi.org/10.1002/j.1556-6676.1988.tb02091.x

Opazo Pérez, K. (2018). Estrategias pedagógicas para abordar la sexualidad al interior de un recinto penal. Revista de Educación de Adultos y Procesos Formativos, 7, 134-155. https://www.educaciondeadultosprocesosformativos.cl/revista/wpcontent/uploads/2019/06/revista_educaciondeadultos_07_08.pdf

Ostrouch-Kamińska J., \& Vieira C.C. (2016). Gender sensitive adult education: Critical perspective. Revista Portuguesa de Pedagogia, 50(1), 37-56. https://impactumjournals.uc.pt/rppedagogia/article/download/1647-8614_50-1_2/3063/14621

Pastor, C., Pérez Conchilo, M., Borrás, J.J., \& Moro, M. (1992). Una Experiencia de Educación Sexual en la Escuela Permanente de Adultos. Revista Brasileira de Sexualidade Humana, 3(2), 191-200.

Risman, A. (2011). Idoso e Educação Sexual: A sexualidade na Sala de Aula. Revista Portal de Divulgaçao, 14, 42-48. https://revistalongeviver.com.br/index.php/revistaportal/article/viewFile/189/189

Rodríguez Maresma, E.C. (2009). Sistema de actividades para fortalecer el valor responsabilidad desde la biología en la educación de adultos (Master Final Project). Instituto Superior Pedagógico "José de la Luz y Caballero" y Sede Universitaria Pedagógica "Calixto García”, Calixto García, Cuba.

Sánchez Sáinz, M. (2009). Cómo educar en la diversidad afectivo-sexual en los centros escolares. Los Libros de la Catarata. 
Sánchez Torrejón, B. (2021). La formación del profesorado de Educación Primaria en diversidad sexogenérica. Revista Electrónica Interuniversitaria De Formación Del Profesorado, 24(1). https://doi.org/10.6018/reifop.393781

Sandín, M.P. (2010). Investigación cualitativa en educación: Fundamentos y tradiciones. McGraw-Hill. Sherlock, L. (2015). Inclusive sex educación: Narratives of good practice from Ireland and Sweden (Doctoral Thesis). Trinity College Dublin, Dublín, Ireland. http://www.tara.tcd.ie/handle/2262/80507

Simons, H. (2011). Estudio de caso: teoría y práctica. Morata.

Sokan, A., \& Teaster, P. (2016). An Overview of Aging and Mistreatment of LGBT Elders. In D.A. Harley \& P.B. Teaster (Eds). Handbook of LGBT Elders - An Interdisciplinary Approach to Principles, Practices, and Policies (pp. 325-342). Springer.

Soler, N.L. (2003). Curso de educación afectivo-sexual: libro de teoría. Netbiblo.

Stake, R. (2010). Qualitative Research: Studying How Things Work. Guilford Publications.

Swain, S., Warne, E., \& Hillel, M. (2004). Ignorance is not innocence: Sex education in Australia, 18901939. In C. Nelson \& M. Martin (Eds.). Sexual pedagogies: Sex education in Britain, Australia, and America, 1879-2000 (pp. 33-52). Palgrave Macmillan.

Titmus, C. (1989). Lifelong Education for Adults - An International Handbook. Pergamon.

Tomaševski, K. (2001). Human rights obligations: making education available, accessible, acceptable and adaptable. Swedish International Development Cooperation Agency - Sida.

UNESCO. (2011). Rio Statement on Homophobic Bullying and Education for All. UNESCO.

Vitòria de Almeida, M. (2019). A educação sexual do idoso em Serra do Mel: medidas de prevenção para infecções sexualmente transmissíveis (Grade Final Project). Universidade Federal Rural Do Semi-Árido, Mossoró, Brasil. https://repositorio.ufersa.edu.br/handle/prefix/3320

Wainerman, C., Di Virgilio, M., \& Chami, N. (2008). La escuela y la educación sexual. Manantial.

Wenger, E. (1998). Communities of Practice: Learning, Meaning, and Identity. Cambridge University Press.

WHO Regional Office for Europe (2010). Estándares de Educación Sexual para Europa. Madrid Salud. Servicio de Prevención y Promoción de la Salud y Salud Ambiental. https://www.bzgawhocc.de/fileadmin/user_upload/Standards_for_sexuality_education_Spanish.pdf

Wie, A-L. (2003). Improving A A $\bar{d}$ ult Learning. https://core.ac.uk/download/pdf/52062584.pdf

Wynee, N. (2008). An analysis of student teacher preparation in relation to homophobia. (Doctoral Thesis). Humboldt State University, California. https://scholarworks.calstate.edu/downloads/kk91fn92q 